\title{
AKTIVITAS INSEKTISIDAEKSTRAK DAUN DAN BIJI TEPHROSIA VOGELII J. D. HOOKER (LEGUMINOSAE) DAN EKSTRAK BUAH PIPER CUBEBA L. (PIPERACEAE) TERHADAPLARVACROCIDOLOMIA PAVONANA (F.) (LEPIDOPTERA: CRAMBIDAE)
}

\author{
Muhamad Abizar $^{1}$ \& Djoko Prijono
}

\begin{abstract}
Insecticidal activity of leaf and seed extracts of Tephrosia vogelii J. D. Hooker (Leguminosae) and fruit extract of Piper cubeba L. (Piperaceae) on the cabbage head caterpillar, Crocidolomia pavonana (L.) (Lepidoptera: Crambidae). Ethyl acetate leaf and seed extracts of Tephrosia vogelii and a solid fraction of ethyl acetate fruit extract of Piper cubeba were evaluated for their insecticidal activity on second-instar larvae Crocidolomia pavonana by a leaf-residue feeding method in the laboratory. Leaf extracts of purple and white-flowered $T$. vogelii showed the same pattern of component separation on silica gel TLC plate (Rf between 0.21 and 0.94), and likewise the separation of components of seed extracts of purple and whiteflowered T. vogelii ( $\mathrm{Rf}$ between 0.31 and 0.96 ). All four kinds of T. vogelii extracts showed intense UV-absorbing nonpolar spots ( $\mathrm{Rf}>0.8)$. Based on $\mathrm{LC}_{50}$ ratio at day 4, leaf extract of purple-flowered T. vogelii $\left(\mathrm{LC}_{50} 0.075 \%\right)$ was 4.30, 2.70, 2.21, and 1.64 times more toxic than fruit extract of $P$. cubeba, seed extract of white-flowered T. vogelii, seed extract of purple-flowered T. vogelii, and leaf extract of white-flowered T. vogelii, respectively. All T. vogelii extracts were more toxic to C. pavonana larvae than P. cubeba fruit extract. At $\mathrm{LC}_{95}$ level, a mixture of leaf extract of purple-flowered T. vogelii and fruit extract of $P$. cubeba $(5: 9, \mathrm{w} / \mathrm{w})$ was more toxic to $C$. pavonana larvae than each extract tested separately. This extract mixture had synergistic joint action against $C$. pavonana larvae both at $\mathrm{LC}_{50}$ and $\mathrm{LC}_{95}$ level. Thus, leaf extract of purple-flowered $T$. vogelii and its mixture with $P$. cubeba fruit extract are promising to be used for controlling C. pavonana.
\end{abstract}

Key words: Botanical insecticides, plant extract mixture, leaf-feeding bioassay, lethal dose ratio, synergistic joint action

\section{PENDAHULUAN}

Sistem pengendalian hama terpadu (PHT) telah ditetapkan sebagai landasan nasional perlindungan tanaman dengan Peraturan Pemerintah No. 6 Tahun 1995. Tindakan PHT menekankan cara-cara pengendalian nonkimia seperti penanaman varietas tahan, pengendalian secara kultur teknis, pengendalian fisik-mekanis, dan pemanfaatan musuh alami, sedangkan insektisida digunakan sebagai alternatif terakhir jika cara-cara nonkimia tidak memberikan hasil yang optimal (Oka, 1995). Insektisida yang dapat digunakan dalam PHT, selain efektif terhadap hama sasaran, harus memenuhi persyaratan keamanan terhadap organisme bukan sasaran, kesehatan dan lingkungan (Sastrosiswojo, 1996). Salah satu golongan insektisida yang memenuhi persyaratan tersebut ialah insektisida botani, yang bersifat mudah terurai di alam, relatif aman terhadap organisme bukan sasaran termasuk musuh alami, dapat dipadukan dengan komponen lain PHT, dan dapat memperlambat laju resistensi (Dadang \& Prijono, 2008).

Genus Tephrosia merupakan sumber insektisida botani yang potensial. Morallo-Rejesus (1986) melaporkan bahwa ekstrak daun kacang babi, T. vogelii, dapat membunuh, menghambat makan, dan menolak larva Plutella xylostella (L.). Wulan (2008) melaporkan bahwa fraksi heksana daun $T$. vogelii pada pengujian dengan metode residu pada daun dan metode kontak dapat mengakibatkan kematian, memperlambat perkembangan larva dan menghambat makan pada larva Crocidolomia pavonana (F.).

Senyawa aktif utama yang bersifat insektisida dalam tanaman $T$. vogelii ialah rotenon dan senyawa rotenoid lain seperti deguelin, tefrosin, dan rotenolon (Delfel et al., 1970; Lambert et al., 1993). Sediaan rotenon dari akar tuba (Derris elliptica) dan beberapa tanaman Leguminosae lain merupakan insektisida botani yang umum digunakan hingga tahun 1950-an sebelum

\footnotetext{
Alumnus Program Mayor S1 Departemen Proteksi Tanaman, Fakultas Pertanian, Institut Pertanian Bogor

2 Departemen Proteksi Tanaman, Fakultas Pertanian, Institut Pertanian Bogor,

Jl. Kamper Kampus Darmaga, Bogor 16680. E-mail: priyonojoko@gmail.com
} 
tergeser oleh insektisida sintetik (Klocke, 1987). Kandungan rotenon pada daun T. vogelii lebih tinggi dibandingkan dengan pada bagian lain (tangkai daun, batang, dan akar) (Delfel et al., 1970). Dengan demikian, penggunaan daun $T$. vogelii sebagai sumber rotenon akan lebih menguntungkan daripada akar tuba karena pemanenan dan penanganan daun lebih mudah dibandingkan dengan akar.

Morallo-Rejesus (1986) menyatakan bahwa bagian tanaman $T$. vogelii yang dapat digunakan sebagai insektisida adalah daun dan biji. Tanaman $T$. vogelii ada yang memiliki bunga berwarna ungu dan berwarna putih (Gaskins et al., 1972; Kardinan, 2002), tetapi sampai sekarang belum pernah ada laporan tentang perbedaan keaktifan sediaan daun dan biji $T$. vogelii berbunga ungu dan putih, sehingga perlu dilakukan pengujian aktivitas insektisida yang terkait dengan hal tersebut.

Insektisida nabati dapat digunakan secara tunggal atau dalam bentuk campuran. Pemanfaatan insektisida nabati berbahan baku dua jenis atau lebih ekstrak tumbuhan dapat mengurangi ketergantungan pada satu jenis tumbuhan sebagai bahan baku sehingga dapat mengatasi keterbatasan bahan baku insektisida nabati di tingkat petani (Dadang \& Prijono, 2008). Selain itu, insektisida dalam bentuk campuran dapat digunakan untuk mengendalikan beberapa jenis hama sekaligus, meningkatkan efisiensi aplikasi karena insektisida dalam campuran digunakan pada dosis yang lebih rendah dibandingkan dengan dosis masing-masing komponennya secara terpisah, terutama bila campuran bersifat sinergis (Stone et al., 1988), menunda timbulnya resistensi hama terhadap insektisida (Georghiou, 1983), dan dapat mengurangi pengaruh samping terhadap organisme bukan sasaran dan lingkungan (Prijono, 2002).

Ekstrak buah kemukus, Piper cubeba L. (Piperaceae), memiliki potensi sinergis jika dicampurkan dengan ekstrak lainnya. Sekitar 18 senyawa lignan yang terdapat dalam buah kemukus memiliki gugus metilendioksifenil di dalam strukturnya (Usia et al., 2005; Elfahmi et al., 2007). Gugus tersebut terdapat dalam sejumlah senyawa sinergis yang dapat menghambat aktivitas enzim sitokrom P450 dalam memetabolisme insektisida (Metcalf, 1967). Beberapa senyawa lignan dari buah kemukus dilaporkan menghambat aktivitas enzim sitokrom P450 3A4 (CYP3A4) dari mikrosoma hati manusia yang berperan dalam memetabolisme senyawa asing termasuk obat-obatan (Usia et al., 2005). Bernard et al. (1989) juga melaporkan bahwa kubebin (salah satu senyawa aktif $P$. cubeba) dapat menghambat aktivitas enzim sitokrom $\mathrm{P} 450$ dari saluran pencernaan ulat penggerek batang, Ostrinia nubilalis Hübner. Terhambatnya enzim pemetabolisme senyawa asing tersebut menyebabkan bahan aktif insektisida atau ekstrak lain yang dicampurkan tidak terurai sehingga insektisida tersebut dapat tetap bekerja mengganggu fungsi bagian sasaran.

Salah satu serangga yang dapat dijadikan sebagai hama sasaran insektisida botani adalah ulat C. pavonana, yang merupakan hama penting pada tanaman sayuran Brassicaceae. Pada fase larva, serangga ini hidup berkelompok dan membutuhkan banyak makanan untuk melangsungkan hidupnya. Larva C. pavonana biasanya memakan habis daun tanaman dan hanya meninggalkan tulang-tulang daun. Larva instar awal umumnya mengonsumsi daun pada permukaan bawah. Pada kubis, serangan lanjut dapat mencapai krop atau titik tumbuh sehingga dapat menyebabkan kegagalan panen. Di Jawa Barat, serangan ulat $C$. pavonana dan $P$. xylostella secara bersamaan dapat mengakibatkan kehilangan hasil sampai $100 \%$ bila tidak dilakukan pengendalian, terutama pada musim kemarau (Sastrosiswojo \& Setiawati, 1993).

Penelitian ini bertujuan mengetahui pengaruh ekstrak daun dan biji $T$. vogelii bunga ungu dan bunga putih, ekstrak buah $P$. cubeba, serta campuran ekstrak T. vogelii yang paling aktif dan ekstrak buah $P$. cubeba terhadap mortalitas dan perkembangan larva C. pavonana.

\section{METODE PENELITIAN}

Penelitian dilaksanakan di Laboratorium Fisiologi dan Toksikologi Serangga, Departemen Proteksi Tanaman, Institut Pertanian Bogor, dari Januari sampai November 2009.

Bahan Tumbuhan Sumber Ekstrak. Bahan tumbuhan yang digunakan sebagai sumber ekstrak adalah daun dan biji $T$. vogelii bunga ungu dan bunga putih yang diperoleh dari kebun organik Bina Sarana Bakti, Cisarua, Bogor (914,4 m dpl, 6²1'17,51 LS dan $106^{\circ} 56^{\prime} 55,42$ BT) dan buah $P$. cubeba yang diperoleh dari pasar lokal di Yogyakarta. Bahan tumbuhan T. vogelii bunga ungu dan putih yang digunakan dalam penelitian ini dipastikan spesiesnya berdasarkan identifikasi oleh staf "Herbarium Bogoriense" Bidang Botani, Pusat Penelitian Biologi, Lembaga Ilmu Pengetahuan Indonesia, Bogor. 
Penyiapan Tanaman Pakan. Tanaman brokoli (Brassica oleracea L. var. italica Plenck) digunakan sebagai pakan serangga uji dan medium perlakuan pada uji hayati di laboratorium. Untuk keperluan pakan serangga uji, tanaman brokoli diperbanyak secukupnya. Benih brokoli cv. Green Magic disemai dalam nampan semai yang diisi media semai campuran tanah dan kompos Super Metan. Bersamaan dengan penyemaian dilakukan pemupukan dengan pupuk majemuk pelepasan perlahan "Dekastar" (NPK 18-9-10+TE). Setelah bibit berumur 4 minggu atau sekurang-kurangnya memiliki empat helai daun, bibit dipindahkan ke polybag kapasitas $5 \mathrm{~kg}$ yang diisi campuran tanah dan pupuk kandang dengan perbandingan 3:1 (v/v). Pada setiap polybag ditanam satu bibit tanaman. Setelah berumur 4 minggu, tanaman dipupuk NPK dengan dosis $\pm 1 \mathrm{~g}$ per polybag. Pupuk ditabur melingkar mengelilingi tanaman, lalu ditutup tanah dan disiram. Pemeliharaan tanaman brokoli yang dilakukan meliputi penyiraman, penyulaman, penyiangan gulma, dan pengendalian hama secara mekanis. Setelah tanaman brokoli berumur 2 bulan, daunnya digunakan sebagai pakan larva C. pavonana.

Pemeliharaan Serangga Uji. Serangga C. pavonana yang digunakan dalam penelitian ini merupakan koloni yang diperbanyak di Laboratorium Fisiologi dan Toksikologi Serangga, Departemen Proteksi Tanaman, Institut Pertanian Bogor. Pembiakan serangga tersebut dilakukan mengikuti prosedur yang dikemukakan oleh Prijono \& Hassan (1992). Larvanya diberi pakan daun brokoli bebas pestisida, yang diperoleh dari perbanyakan tanaman pakan yang diuraikan pada bagian sebelumnya, dan imagonya diberi pakan larutan madu $10 \%$ yang diserapkan pada segumpal kapas.

Ekstraksi Bahan Tumbuhan. Daun dan biji T. vogelii bunga ungu dan bunga putih dikeringanginkan, kemudian daunnya dipotong menjadi bagian-bagian kecil dan digiling menggunakan blender hingga menjadi serbuk, sedangkan bijinya ditumbuk menggunakan alat penumbuk dari batu lalu digiling dengan blender. Buah P. cubeba langsung digiling dengan blender. Setiap bahan tumbuhan yang sudah diblender diayak menggunakan pengayak kawat kasa berjalinan $0,5 \mathrm{~mm}$.

Serbuk daun $T$. vogelii $300 \mathrm{~g}$, biji T. vogelii $100 \mathrm{~g}$, dan buah $P$. cubeba $500 \mathrm{~g}$, masing-masing direndam dalam $3 \mathrm{~L}, 1 \mathrm{~L}$, dan $1,5 \mathrm{~L}$ etil asetat selama 24 jam. Rendaman masing-masing serbuk tumbuhan kemudian disaring menggunakan corong kaca yang dialasi kertas saring Whatman No. 41. Hasil saringan kemudian diuapkan dengan menggunakan rotary evaporator pada suhu $50^{\circ} \mathrm{C}$ dan tekanan 240 mbar. Etil asetat hasil penguapan yang diperoleh digunakan kembali untuk membilas residu pada perendaman dan corong kaca. Pembilasan dan perendaman ini dilakukan berulang-ulang sehingga pada perendaman terakhir larutan hasil penyaringan berwarna sangat muda (hampir tidak berwarna).

Ekstrak yang diperoleh dari daun $T$. vogelii berbentuk padat dan berwarna hijau pekat, ekstrak biji T. vogelii berbentuk padat dan berwarna cokelat kemerahan, dan ekstrak buah $P$. cubeba berbentuk campuran fraksi minyak dan fraksi padatan yang berwarna cokelat kemerahan. Fraksi padatan ekstrak $P$. cubeba digunakan untuk pengujian setelah dipisahkan dari fraksi minyaknya. Setiap ekstrak yang diperoleh disimpan dalam lemari es $\left( \pm 4^{\circ} \mathrm{C}\right)$ hingga saat digunakan.

Pemeriksaan Kualitatif Komponen Ekstrak T. vogelii. Pemisahan komponen empat jenis ekstrak T. vogelii diperiksa secara kualitatif dengan teknik kromatografi lapisan tipis (thin layer chromatographyTLC), dengan menggunakan pelat aluminium TLC berlapiskan gel silika (Silica Gel F ${ }_{254}$, Merck) dan larutan pengembang campuran kloroform dan dietileter (19:1), serta visualisasi komponen ekstrak dengan sinar UV 254 nm (Kamal \& Mangla, 1993). Hasil pemeriksaan menunjukkan bahwa pemisahan komponen ekstrak daun T. vogelii bunga ungu dan bunga putih memiliki pola yang sama, demikian pula pemisahan komponen ekstrak biji T. vogelii bunga ungu dan bunga putih (Gambar 1). Intensitas bercak pada ekstrak daun $T$. vogelii lebih tinggi dibandingkan dengan ekstrak biji. Ekstrak daun T. vogelii bunga ungu dan putih mengandung enam subfraksi dengan Rf antara 0,21 dan 0,94, sedangkan ekstrak biji $T$. vogelii bunga ungu dan bunga putih mengandung lima subfraksi dengan Rf antara 0,31 dan 0,96 (Tabel 1). Pada keempat jenis ekstrak, bercak nonpolar $(\mathrm{Rf}>0,8)$ tampak jelas, selain komponen polar yang tetap berada di dekat garis dasar pelat TLC (Gambar 1).

Metode Pengujian. Setiap jenis ekstrak diuji pada enam taraf konsentrasi yang diharapkan dapat mematikan serangga uji antara $15 \%$ dan $95 \%$, yang ditentukan berdasarkan uji pendahuluan. Konsentrasi uji ekstrak daun $T$. vogelii bunga ungu ialah $0,05 \%$, $0,08 \%, 0,11 \%, 0,14 \%, 0,18 \%$ dan $0,22 \%$ (w/v). 


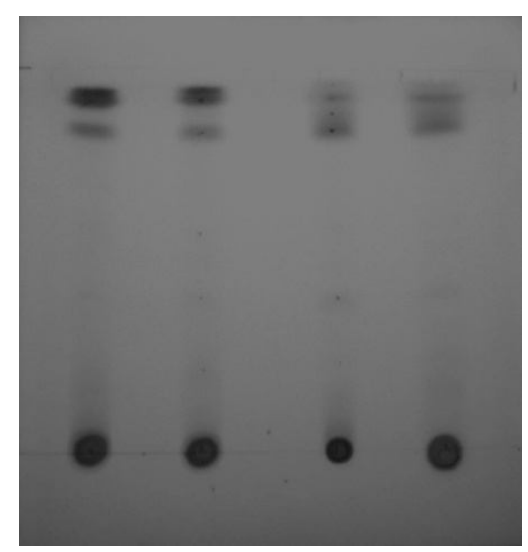

Gambar 1. Hasil pemeriksaan kualitatif empat jenis ekstrak T. vogelii (T.v.) dengan TLC gel silika. Sampel dari kiri ke kanan berturut-turut ekstrak daun T.v. bunga ungu, ekstrak daun T.v. bunga putih, ekstrak biji T.v. bunga ungu, dan ekstrak biji T.v. bunga putih

Tabel 1. Faktor retensi komponen ekstrak T. vogelii pada pelat TLC gel silika

\begin{tabular}{cc}
\hline Jenis ekstrak & Faktor retensi (Rf) \\
\hline Ekstrak daun T. vogelii bunga ungu dan bunga putih & $0^{*} ; 0,21 ; 0,39 ; 0,83^{*} ; 0,89 ; 0,91^{*} ; 0,94^{*}$ \\
Ekstrak biji T. vogelii bunga ungu dan bunga putih & $0^{*} ; 0,31 ; 0,84^{*} ; 0,89^{*} ; 0,93 * ; 0,96$ \\
\hline
\end{tabular}

${ }^{*}$ Subfraksi utama (bercak tampak jelas)

Konsentrasi uji ekstrak daun T. vogelii bunga putih dan ekstrak biji $T$. vogelii bunga ungu dan putih sama, yaitu $0,05 \%, 0,12 \%, 0,19 \%, 0,26 \%, 0,33 \%$ dan $0,40 \%$. Konsentrasi uji fraksi padatan ekstrak buah ialah $0,25 \%$, $0,32 \%, 0,39 \%, 0,46 \%, 0,53 \%$ dan $0,60 \%(\mathrm{w} / \mathrm{v})$. Konsentrasi total campuran ekstrak daun $T$. vogelii bunga ungu dan ekstrak P. cubeba (5:9) yang diuji ialah $0,07 \%, 0,126 \%, 0,182 \%, 0,238 \%, 0,294 \%$ dan $0,350 \%$.

Ekstrak daun dan biji $T$. vogelii dicampur dengan pelarut metanol dan pengemulsi Tween-80 (5:1) kemudian diencerkan dengan akuades sampai volume tertentu sesuai konsentrasi yang diinginkan. Konsentrasi akhir metanol dan Tween-80 dalam suspensi ekstrak uji masing-masing $1 \%$ dan $0,2 \%(\mathrm{v} / \mathrm{v})$. Air yang mengandung pelarut metanol $1 \%$ dan pengemulsi Tween80 0,2\% digunakan sebagai larutan kontrol. Fraksi padatan ekstrak buah $P$. cubeba dicampur dengan campuran aseton, metanol, dan Tween-80 (2,5:7,5:2, konsentrasi akhir $0,25 \%, 0,75 \%$ dan $0,2 \%$ ) kemudian diencerkan dengan akuades sampai volume tertentu sesuai konsentrasi yang diinginkan. Larutan kontrol berupa akuades yang mengandung aseton $0,25 \%$, metanol $0,75 \%$ dan Tween-80 0,2\%. Untuk pengujian campuran, ekstrak daun $T$. vogelii bunga ungu dan fraksi padatan ekstrak buah P. cubeba $(5: 9$, w/w) dicampur dengan campuran aseton, metanol dan Tween$80(5: 5: 2$, konsentrasi akhir $0,5 \%, 0,5 \%$, dan $0,2 \%)$ kemudian diencerkan dengan akuades sampai volume tertentu sesuai konsentrasi yang diinginkan. Larutan kontrol berupa akuades yang mengandung aseton $0,5 \%$, metanol 0,5\% dan Tween-80 0,2\%. Semua suspensi ekstrak dikocok dengan mengunakan pengocok ultrasonik agar ekstrak dapat tersuspensikan secara merata di dalam air. 
Pengujian dilakukan dengan menggunakan metode celup daun. Potongan daun brokoli segar berukuran $4 \mathrm{~cm} \times 4 \mathrm{~cm}$ dan bebas pestisida dicelup satu per satu dalam suspensi ekstrak uji sampai basah merata lalu dikeringudarakan. Daun kontrol dicelup dalam larutan kontrol yang sesuai. Setiap potong daun perlakuan dan daun kontrol diletakkan secara terpisah di dalam cawan petri (diameter $9 \mathrm{~cm}$ ) yang dialasi tisu. Sebanyak 15 ekor larva instar II $C$. pavonana $(<30$ menit setelah ganti kulit) dimasukkan ke dalam cawan petri, kemudian diberikan daun kontrol atau daun perlakuan sesuai konsentrasinya (satu daun/cawan), dan larva tersebut dibiarkan makan selama 24 jam. Setelah 24 jam ditambahkan daun perlakuan atau daun kontrol secukupnya. Dua puluh empat jam berikutnya, daun perlakuan diganti dengan daun tanpa perlakuan. Setiap perlakuan diulang enam kali. Jumlah larva yang mati dicatat setiap hari sampai hari ke-4 (96 jam sejak awal perlakuan [JAP]).

Data mortalitas kumulatif pada 48, 72 dan 96 JAP diolah dengan analisis probit menggunakan program POLO-PC (LeOra Software, 1987). Pembandingan toksisitas di antara ekstrak tunggal dilakukan dengan cara menghitung nisbah $\mathrm{LC}_{50}$ dan selang kepercayaan (SK) 95\%-nya (Robertson et al., 2007).

Penentuan Sifat Aktivitas Campuran Ekstrak $T$. vogelii dan P. cubeba. Sifat aktivitas campuran ekstrak T. vogelii yang paling aktif dan fraksi padatan ekstrak buah $P$. cubeba dianalisis berdasarkan model kerja bersama berbeda dengan menghitung indeks kombinasi (IK) pada taraf $\mathrm{LC}_{50}$ dan $\mathrm{LC}_{95}$ (Chou \& Talalay, 1984):

$\mathrm{IK}=\frac{\mathrm{LC}_{\mathrm{x}}{ }^{1(\mathrm{~cm})}}{\mathrm{LC}_{\mathrm{x}}{ }^{1}}+\frac{\mathrm{LC}_{\mathrm{x}}{ }^{2(\mathrm{~cm})}}{\mathrm{LC}_{\mathrm{x}}{ }^{2}}+\left(\frac{\mathrm{LC}_{\mathrm{x}}{ }^{1(\mathrm{~cm})}}{\mathrm{LC}_{\mathrm{x}}{ }^{1}} \mathrm{x} \frac{\mathrm{LC}_{\mathrm{x}}{ }^{2(\mathrm{~cm})}}{\mathrm{LC}_{\mathrm{x}}{ }^{2}}\right)$

$\mathrm{LC}_{\mathrm{x}}{ }^{1}$ dan $\mathrm{LC}_{\mathrm{x}}{ }^{2}$ masing-masing merupakan $\mathrm{LC}_{\mathrm{x}}$ ekstrak T. vogelii yang paling aktif dan fraksi padatan ekstrak buah $P$. cubeba pada pengujian terpisah; $\mathrm{LC}_{\mathrm{x}}{ }^{1(\mathrm{~cm})}$ dan $\mathrm{LC}_{\mathrm{x}}{ }^{2(\mathrm{~cm})}$ masing-masing LC komponen $T$. vogelii yang paling aktif dan $P$. cubeba dalam campuran yang mengakibatkan mortalitas x (misal 50\% dan 95\%). Nilai $\mathrm{LC}$ tersebut diperoleh dengan cara mengalikan $\mathrm{LC}_{\mathrm{x}}$ campuran dengan proporsi konsentrasi komponen T. vogelii dan $P$. cubeba dalam campuran.
Kategori sifat interaksi campuran adalah sebagai berikut (diadaptasi dari Gisi, 1996 dan Kosman \& Cohen, 1996): (1) bila IK < 0,5 komponen campuran bersifat sinergistik kuat; (2) bila $0,5 \leq \mathrm{IK} \leq 0,77$ komponen campuran bersifat sinergistik lemah; (3) bila $0,77<\mathrm{IK}$ $\leq 1,43$ komponen campuran bersifat aditif; (4) bila IK > 1,43 komponen campuran bersifat antagonistik.

\section{HASIL DAN PEMBAHASAN}

\section{Pengaruh Ekstrak Uji terhadap Mortalitas Larva} C. pavonana. Tingkat kematian larva $C$. pavonana pada 24 JAP masih rendah untuk semua perlakuan. Peningkatan kematian serangga uji mulai tampak nyata pada 48 JAP dan umumnya meningkat dengan makin besarnya konsentrasi yang diuji (Gambar 2). Pada 48 JAP perlakuan dengan empat jenis ekstrak $T$. vogelii pada konsentrasi tertinggi mengakibatkan kematian larva $\geq 80 \%$ (Gambar 2 A-D), sedangkan perlakuan ekstrak buah $P$. cubeba dan campuran ekstrak daun $T$. vogelii bunga ungu + ekstrak buah $P$. cubeba (5:9) pada konsentrasi tertinggi mengakibatkan kematian larva 100\% (Gambar 2 E-F). Pada 72 JAP masih terjadi peningkatan kematian larva pada perlakuan yang kematiannya belum mencapai $100 \%$, meskipun daun perlakuan sudah diganti dengan daun tanpa perlakuan. Pada perlakuan empat jenis ekstrak $T$. vogelii pada konsentrasi tertinggi, mortalitas larva bertambah menjadi $90 \%$, sementara perlakuan ekstrak buah $P$. cubeba dan campuran ekstrak daun $T$. vogelii bunga ungu + ekstrak buah $P$. cubeba pada lima konsentrasi tertinggi mengakibatkan kematian larva $\geq 50 \%$. Untuk semua perlakuan, kematian larva umumnya hanya sedikit meningkat setelah 72 JAP. Pola perkembangan mortalitas larva $C$. pavonana tersebut menunjukkan bahwa senyawa aktif dalam empat jenis ekstrak T. vogelii dan ekstrak buah $P$. cubeba bekerja relatif lambat.

Semua data yang mengandung tingkat mortalitas $\geq 50 \%$ diolah dengan analisis probit untuk menentukan hubungan konsentrasi-mortalitas, termasuk menentukan $\mathrm{LC}_{50}$ dan $\mathrm{LC}_{95}$. Berdasarkan sifat data yang diperoleh, analisis probit dilakukan terhadap data kematian larva pada 48, 72, dan 96 JAP. Hasil analisis probit untuk semua perlakuan menunjukkan bahwa nilai $\mathrm{LC}_{50}$ dan $\mathrm{LC}_{95}$ pada $96 \mathrm{JAP}$ lebih kecil daripada $\mathrm{LC}_{50}$ dan $\mathrm{LC}_{95}$ 


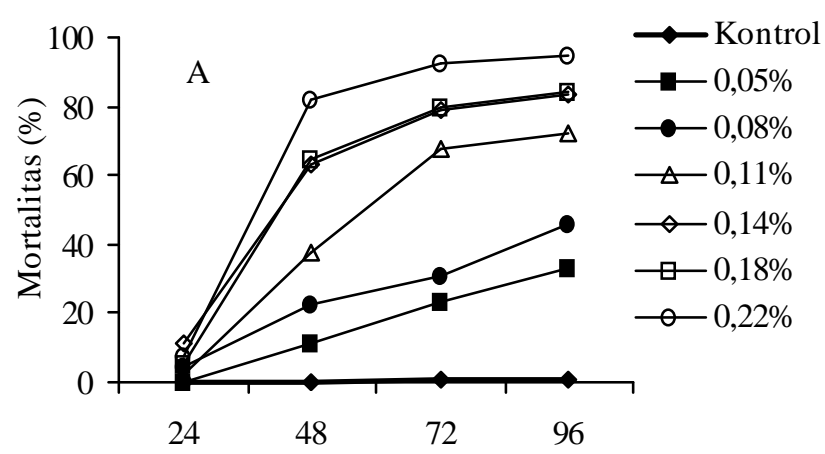

Waktu pengamatan (JAP)
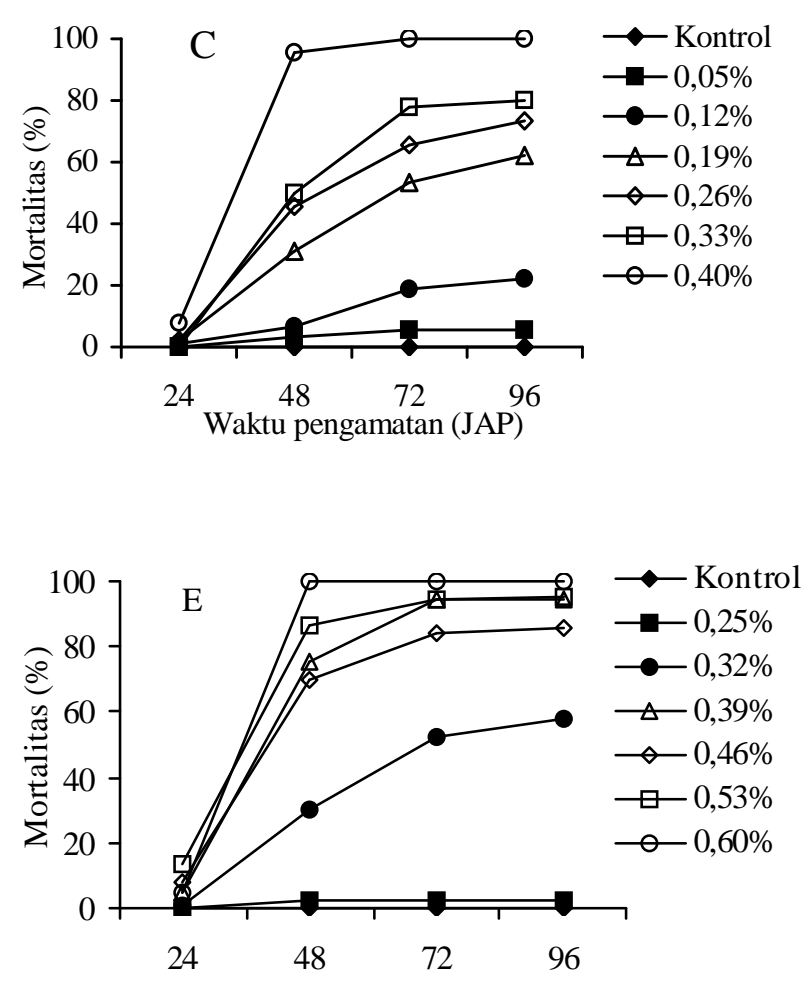

Waktu pengamatan (JAP)

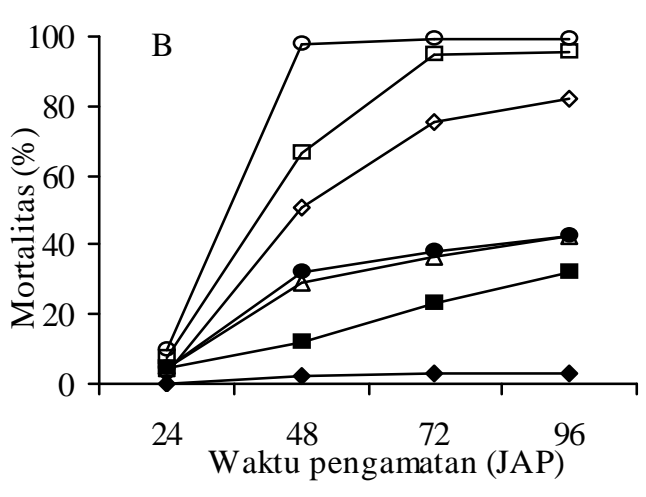

$\longrightarrow$ Kontro
$\rightarrow-0,05 \%$
$\rightarrow-0,12 \%$
$\triangle-0,19 \%$
$-0,26 \%$
$\rightarrow 0,33 \%$
$\rightarrow-0,40 \%$
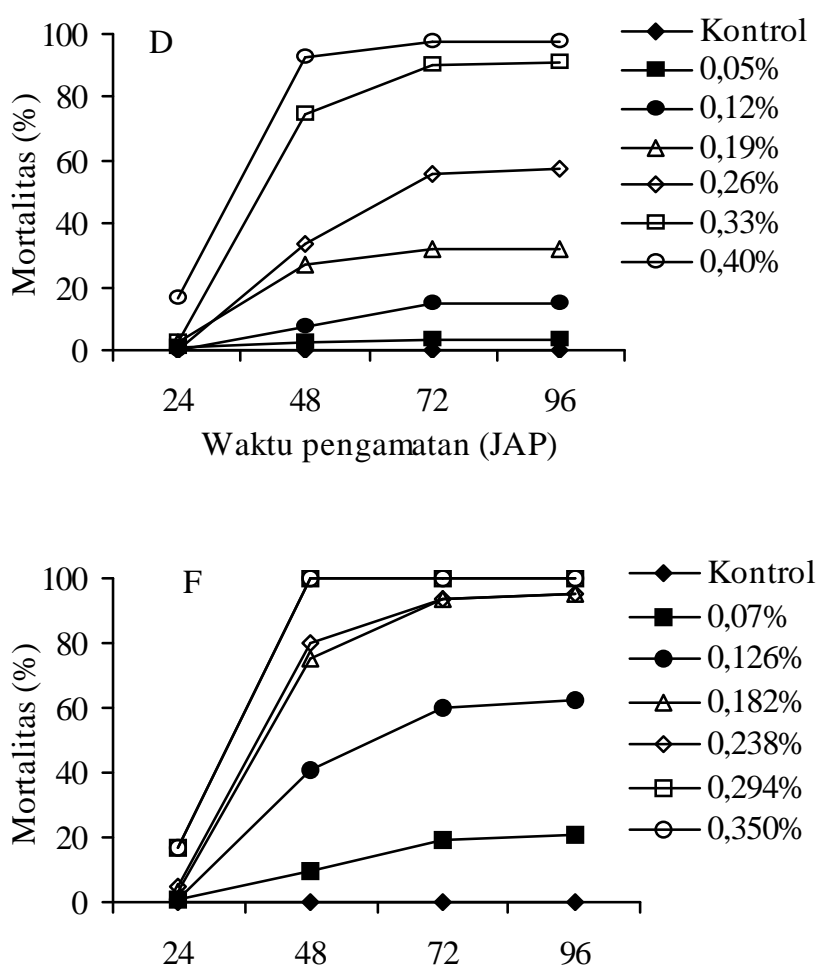

Waktu pengamatan (JAP)

Gambar 2. Perkembangan mortalitas larva C. pavonana pada perlakuan ekstrak daun $T$. vogelii bunga ungu (A), ekstrak daun T. vogelii bunga putih (B), ekstrak biji $T$. vogelii bunga ungu (C), ekstrak biji $T$. vogelii bunga putih (D), ekstrak buah $P$. cubeba (E), dan campuran ekstrak daun $T$. vogelii bunga ungu dan ekstrak buah $P$. cubeba (5:9) (F). JAP = jam sejak awal perlakuan 


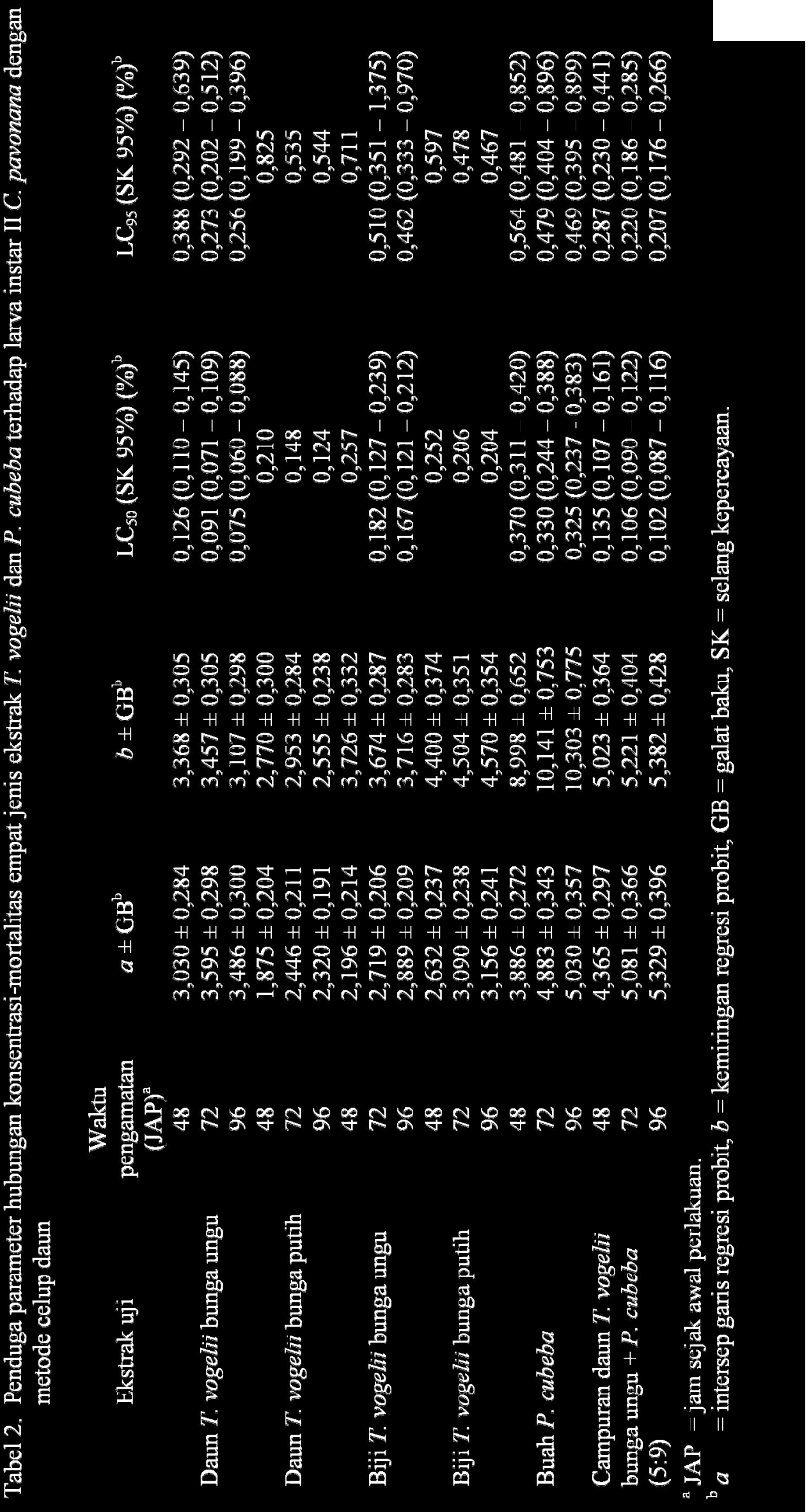


pada $72 \mathrm{JAP}$ yang juga lebih kecil daripada $\mathrm{LC}_{50}$ dan $\mathrm{LC}_{95}$ pada $48 \mathrm{JAP}$ (Tabel 2). Hal ini konsisten dengan pola perkembangan mortalitas larva seperti yang diuraikan di atas, yaitu pada 72 dan 96 JAP masih terjadi peningkatan kematian larva.

Ekstrak daun $T$. vogelii bunga ungu memiliki aktivitas insektisida yang kuat terhadap larva $C$. pavonana karena $\mathrm{LC}_{95}$-nya pada 72 dan 96 JAP tidak lebih besar dari 0,3\%. Sementara itu, ekstrak biji $T$. vogelii bunga ungu dan bunga putih serta ekstrak buah P. cubeba memiliki aktivitas insektisida cukup kuat karena $\mathrm{LC}_{95}$-nya pada 72 dan 96 JAP sekitar $0,5 \%$, dan toksisitas ekstrak daun $T$. vogelii bunga putih lebih rendah dibandingkan dengan tiga jenis ekstrak $T$. vogelii lainnya (Tabel 2).

Berdasarkan kesetaraan toksisitas pada taraf $\mathrm{LC}_{50}$ pada $96 \mathrm{JAP}$, ekstrak daun $T$. vogelii bunga ungu berturut-turut 4,30; 2,70; 2,21; dan 1,64 kali lebih toksik dibandingkan dengan ekstrak buah $P$. cubeba, ekstrak biji $T$. vogelii bunga putih, ekstrak biji $T$. vogelii bunga ungu, dan ekstrak daun $T$. vogelii bunga putih; toksisitas ekstrak daun $T$. vogelii bunga ungu tersebut berbeda

Tabel 3. Kesetaraan toksisitas di antara empat macam ekstrak T. vogelii dan $P$. cubeba terhadap larva C. pavonana berdasarkan nisbah $\mathrm{LC}_{50}$ dan selang kepercayaan (SK) $95 \%$

\begin{tabular}{|c|c|c|c|c|}
\hline \multirow{2}{*}{ Ekstrak $^{\mathrm{a}}$} & \multicolumn{4}{|c|}{ Nisbah LC $_{50}(\text { SK 95\% })^{\mathrm{c}}$} \\
\hline & T. vogelii-1 & T. vogelii-2 & T. vogelii-3 & T. vogelii-4 \\
\hline \multicolumn{5}{|l|}{$48 \mathrm{JAP}^{\mathrm{b}}$} \\
\hline P. cubeba & $\begin{array}{c}1,467 \\
(0,591-3,636)\end{array}$ & $\begin{array}{c}1,437 \\
(0,582-3,552)\end{array}$ & $\begin{array}{c}1,759 \\
(0,739-4,184)\end{array}$ & $\begin{array}{c}2,936 \\
(1,307-6,598)\end{array}$ \\
\hline T. vogelii-1 & - & $\begin{array}{c}1,020 \\
(0,498-2,092)\end{array}$ & $\begin{array}{c}1,199 \\
(0,614-2,342)\end{array}$ & $\begin{array}{c}2,002 \\
(1,106-, 625)\end{array}$ \\
\hline T. vogelii- 2 & & - & $\begin{array}{c}1,224 \\
(0,629-2,379)\end{array}$ & $\begin{array}{c}2,043 \\
(1,134-3,680)\end{array}$ \\
\hline T. vogelii-3 & & & - & $\begin{array}{c}1,670 \\
(0,985-2,831)\end{array}$ \\
\hline \multicolumn{5}{|l|}{$72 \mathrm{JAP}^{\mathrm{b}}$} \\
\hline P. cubeba & $\begin{array}{c}1,601 \\
(0,647-3,946)\end{array}$ & $\begin{array}{c}1,814 \\
(0,752-4,371)\end{array}$ & $\begin{array}{c}2,224 \\
(0,922-5,365)\end{array}$ & $\begin{array}{c}3,620 \\
(1,578-8,300)\end{array}$ \\
\hline T. vogelii-1 & - & $\begin{array}{c}1,133 \\
(0,610-2,104)\end{array}$ & $\begin{array}{c}1,389 \\
(0,747-2,584)\end{array}$ & $\begin{array}{c}2,261 \\
(1,309-3,904)\end{array}$ \\
\hline T. vogelii- 2 & & - & $\begin{array}{c}1,226 \\
(0,681-2,207)\end{array}$ & $\begin{array}{c}1,996 \\
(1,200-3,320)\end{array}$ \\
\hline T. vogelii-3 & & & - & $\begin{array}{c}1,628 \\
(0,977-2,712)\end{array}$ \\
\hline \multicolumn{5}{|l|}{$96 \mathrm{JAP}^{\mathrm{b}}$} \\
\hline P. cubeba & $\begin{array}{c}1,594 \\
(0,644-3,945)\end{array}$ & $\begin{array}{c}1,947 \\
(0,806-4,703)\end{array}$ & $\begin{array}{c}2,629 \\
(1,105-6,256)\end{array}$ & $\begin{array}{c}4,302 \\
(1,858-9,961)\end{array}$ \\
\hline T. vogelii-1 & - & $\begin{array}{c}1,222 \\
(0,659-2,264)\end{array}$ & $\begin{array}{c}1,650 \\
(0,909-2,992)\end{array}$ & $\begin{array}{c}2,699 \\
(1,550-4,702)\end{array}$ \\
\hline T. vogelii- 2 & & - & $\begin{array}{c}1,350 \\
(0,773-2,356)\end{array}$ & $\begin{array}{c}2,209 \\
(1,322-3,692)\end{array}$ \\
\hline T. vogelii-3 & & & - & $\begin{array}{c}1,636 \\
(1,005-2,665)\end{array}$ \\
\hline
\end{tabular}

${ }^{a}$ Kode 1 s.d. 4 untuk T. vogelii (T.v.) berturut-turut (1) ekstrak biji T.v. bunga putih, (2) ekstrak biji T.v. bunga ungu, (3) ekstrak daun T.v. bunga putih, dan (4) ekstrak daun T.v. bunga ungu.

${ }^{\mathrm{b}}$ Waktu pengamatan, JAP = jam sejak awal perlakuan.

${ }^{c} \mathrm{LC}_{50}$ ekstrak pada kolom ke-1 dibagi $\mathrm{LC}_{50}$ ekstrak pada kolom ke-2 dan seterusnya, kecuali pada $48 \mathrm{JAP}$ T.v.-1/T.v.-2 nisbah tersebut merupakan $\mathrm{LC}_{50}$ T.v-2 kolom ke-3 dibagi LC $_{50}$ T.v-1 kolom ke-1. 
nyata dengan toksisitas empat jenis ekstrak lainnya (SK 95\% dari nisbah $L_{50}$ tidak melewati nilai 1) (Tabel 3). Pada 48 dan 72 JAP, toksisitas ekstrak daun $T$. vogelii bunga ungu juga berbeda nyata dengan toksisitas ekstrak buah $P$. cubeba, ekstrak biji $T$. vogelii bunga putih, dan ekstrak biji $T$. vogelii bunga ungu, tetapi tidak berbeda nyata dengan toksisitas ekstrak daun $T$. vogelii bunga putih (SK 95\% dari nisbah $\mathrm{LC}_{50}$ melewati nilai 1).

Toksisitas ekstrak daun $T$. vogelii bunga putih pada taraf $\mathrm{LC}_{50}$ pada 48, 72, dan 96 JAP masing-masing 1,76; 2,22; dan 2,63 kali lebih tinggi dibandingkan dengan toksisitas ekstrak buah $P$. cubeba, tetapi toksisitas yang berbeda nyata hanya terdapat pada pengamatan 96 JAP. Toksisitas ekstrak daun $T$. vogelii bunga putih tidak berbeda nyata dengan toksisitas ekstrak biji $T$. vogelii bunga ungu dan bunga putih meskipun nisbah $\mathrm{LC}_{50}$ nya $1,20-1,65$. Ekstrak biji $T$. vogelii bunga ungu memiliki toksisitas yang tidak berbeda nyata dengan ekstrak biji $T$. vogelii bunga putih dengan nisbah $\mathrm{LC}_{50}$ 1,02-1,22. Toksisitas kedua ekstrak biji T. vogelii tersebut juga tidak berbeda nyata dengan toksisitas ekstrak buah $P$. cubeba, meskipun nisbah $\mathrm{LC}_{50}$-nya berkisar dari 1,44 sampai 1,95 (Tabel 3). Secara umum dapat dikemukakan bahwa ekstrak daun $T$. vogelii lebih aktif dibandingkan dengan ekstrak bijinya dan ekstrak yang berasal dari tanaman $T$. vogelii berbunga ungu lebih aktif daripada ekstrak $T$. vogelii berbunga putih. Keempat jenis ekstrak $T$. vogelii tersebut lebih aktif dibandingkan dengan ekstrak buah $P$. cubeba.

Hasil penelitian ini sesuai dengan laporan MoralloRejesus (1986) yang menyatakan bahwa bagian tanaman $T$. vogelii yang dapat digunakan sebagai insektisida adalah daun dan biji. Pemeriksaan kualitatif ekstrak T. vogelii dengan TLC gel silika menunjukkan perbedaan pola bercak antara ekstrak daun dan ekstrak biji. Ekstrak daun $T$. vogelii mengandung senyawa nonpolar lebih banyak yang tampaknya menyebabkan ekstrak bersifat aktif (Gambar 2, Tabel 1). Ekstrak daun T. vogelii bunga ungu lebih aktif dibandingkan dengan ekstrak daun T. vogelii bunga putih, serta ekstrak biji $T$. vogelii bunga ungu dan bunga putih. Dengan demikian, pengembangan insektisida botani berbahan baku $T$. vogelii lebih disarankan menggunakan daun $T$. vogelii bunga ungu dibandingkan dengan biji $T$. vogelii bunga ungu atau daun dan biji $T$. vogelii bunga putih. Selain pembuatan ekstrak daun $T$. vogelii lebih praktis dan hemat biaya, ketersediaan daun juga lebih banyak dibandingkan dengan biji.

Aktivitas ekstrak daun T. vogelii bunga ungu yang lebih tinggi dibandingkan dengan tiga jenis ekstrak T. vogelii lainnya kemungkinan ekstrak tersebut memiliki kandungan senyawa aktif rotenoid yang lebih tinggi. Tiga jenis senyawa rotenoid utama yang bersifat insektisida dalam tanaman $T$. vogelii adalah rotenon, deguelin, dan tefrosin (Delfel et al., 1970; Lambert et al., 1993). Rotenon dan deguelin lebih banyak terdapat dalam daun daripada dalam tangkai daun dan batang, serta paling sedikit dalam akar (Delfel et al., 1970).

Rotenon bekerja sebagai racun respirasi dengan cara menghambat transfer elektron dalam NADHkoenzim ubiquinon reduktase (kompleks I) dari sistem transpor elektron di dalam mitokondria (Hollingworth, 2001). Hambatan ini akan menurunkan produksi ATP, selanjutnya menghambat aktivitas sel, mengakibatkan kelumpuhan akibat otot dan jaringan lain kekurangan energi, dan akhirnya mengakibatkan kematian (Perry et al., 1998). Tubuh larva C. pavonana yang keracunan ekstrak $T$. vogelii tampak menghitam yang mencerminkan terjadinya kematian sel dan jaringan.

Tabel 4. Sifat aktivitas campuran ekstrak daun T. vogelii bunga ungu dan buah P. cubeba (5:9) terhadap larva instar II C. pavonana dengan metode celup daun

\begin{tabular}{ccccc}
\hline \multirow{2}{*}{$\begin{array}{c}\text { Waktu pengamatan } \\
(\mathrm{JAP})^{\mathrm{a}}\end{array}$} & \multicolumn{2}{c}{ Indeks kombinasi } & \multicolumn{2}{c}{ Sifat Interaksi } \\
\cline { 2 - 5 } & $\mathrm{LC}_{50}$ & $\mathrm{LC}_{95}$ & Sinergistik lemah & Sinergistik lemah \\
\hline 48 & 0,710 & 0,680 & Sinergistik lemah & Sinergistik lemah \\
72 & 0,708 & 0,668 & Sinergistik kuat & Sinergistik lemah \\
96 & 0,245 & 0,655 &
\end{tabular}

${ }^{\mathrm{a}} \mathrm{JAP}=$ jam sejak awal perlakuan. 
Sifat Aktivitas Campuran Ekstrak $T$. vogelii dan P. cubeba. $\mathrm{LC}_{50}$ campuran ekstrak daun $T$. vogelii bunga ungu + buah $P$. cubeba (5:9) sekitar 1,07-1,36 kali lebih tinggi dibandingkan dengan $\mathrm{LC}_{50}$ ekstrak daun T. vogelii bunga ungu, tetapi hanya sekitar 2,74-3,19 kali lebih rendah daripada $\mathrm{LC}_{50}$ ekstrak buah $P$. cubeba, serta $\mathrm{LC}_{95}$ campuran tersebut sekitar 1,24-1,35 kali lebih rendah dibandingkan dengan $\mathrm{LC}_{95}$ ekstrak daun $T$. vogelii bunga ungu dan sekitar 1,97-2,27 kali lebih rendah daripada $\mathrm{LC}_{95}$ ekstrak buah $P$. cubeba (Tabel 2). Dengan demikian pada taraf $\mathrm{LC}_{95}$ campuran ekstrak daun $T$. vogelii bunga ungu + buah $P$. cubeba lebih aktif terhadap larva $C$. pavonana dibandingkan dengan ekstrak daun T. vogelii bunga ungu dan buah $P$. cubeba secara terpisah.

Pada taraf $\mathrm{LC}_{50}$, campuran ekstrak daun $T$. vogelii bunga ungu dan buah $P$. cubeba bersifat sinergistik lemah pada 48 dan 72 JAP dan sinergistik kuat pada 96 JAP, sedangkan pada taraf $\mathrm{LC}_{95}$ campuran tersebut bersifat sinergistik lemah baik pada 48, 72 maupun 96 JAP (Tabel 4). Peningkatan sifat sinergistik pada taraf $\mathrm{LC}_{50}$ dari sinergistik lemah pada 72 JAP menjadi sinergistik kuat pada 96 JAP mencerminkan terjadinya peningkatan mortalitas larva $C$. pavonana yang lebih besar pada perlakuan campuran ekstrak pada 96 JAP dibandingkan dengan peningkatan mortalitas pada perlakuan ekstrak tunggal. Campuran ekstrak daun $T$. vogelii bunga ungu dan buah $P$. cubeba yang bersifat sinergistik layak diuji lebih lanjut di lapangan.

Sifat sinergistik campuran ekstrak daun T. vogelii bunga ungu dan buah $P$. cubeba kemungkinan disebabkan oleh adanya senyawa lignan yang mengandung gugus metilendioksifenil dalam buah $P$. cubeba, seperti kubebin, klusin, dihidroklusin, yatein, hinokinin, dan dihidrokubebin (Usia et al., 2005; Elfahmi et al., 2007). Gugus fungsional tersebut merupakan ciri penting dari sejumlah sinergis insektisida yang dapat menghambat aktivitas enzim sitokrom P450, yang dapat menurunkan daya racun senyawa asing termasuk insektisida (Metcalf, 1967; Bernard et al., 1989). Dengan terhambatnya enzim penurun daya racun senyawa asing tersebut kemungkinan senyawa aktif ekstrak $T$. vogelii yang dicampurkan tidak terurai dan dapat tetap bekerja. Dengan demikian, penggunaan campuran ekstrak daun $T$. vogelii bunga ungu dan ekstrak buah $P$. cubeba lebih disarankan dibandingkan dengan penggunaan komponennya secara terpisah di lapangan.

Penggunaan campuran insektisida botani yang bersifat sinergistik dapat meningkatkan efisiensi aplikasi karena insektisida campuran digunakan pada dosis yang lebih rendah dibandingkan dengan dosis komponen masing-masing secara terpisah. Dengan kata lain, penggunaan campuran insektisida botani yang bersifat sinergistik dapat mengurangi jumlah pemakaian bahan baku dibandingkan dengan insektisida botani yang mengandung ekstrak tunggal, sehingga dapat mengatasi keterbatasan bahan baku insektisida botani di tingkat petani karena tumbuhan sumber insektisida botani tidak selalu terdapat melimpah di suatu daerah. Penggunaan campuran insektisida botani pada dosis yang lebih rendah juga dapat mengurangi dampak samping terhadap organisme bukan sasaran dan lingkungan. Selain itu, penggunaan campuran insektisida botani yang komponennya memiliki cara kerja berbeda dapat menunda terjadinya resistensi hama (Georghiou, 1983).

\section{SIMPULAN}

Ekstrak etil asetat daun dan biji T. vogelii bunga ungu dan bunga putih dan fraksi padatan ekstrak etil asetat buah $P$. cubeba memiliki aktivitas insektisida yang kuat terhadap larva instar II $C$. pavonana. Ekstrak daun $T$. vogelii lebih aktif dibandingkan dengan ekstrak biji dan ekstrak yang berasal dari tanaman $T$. vogelii bunga ungu lebih aktif daripada ekstrak $T$. vogelii bunga putih. Keempat jenis ekstrak T. vogelii tersebut lebih aktif dibandingkan dengan ekstrak buah $P$. cubeba. Campuran ekstrak daun $T$. vogelii bunga ungu + fraksi padatan ekstrak buah $P$. cubeba (5:9) bersifat sinergistik terhadap larva $C$. pavonana, baik pada taraf $\mathrm{LC}_{50}$ maupun $\mathrm{LC}_{95}$. Ekstrak daun T. vogelii bunga ungu dan campurannya dengan ekstrak buah $P$. cubeba berpotensi untuk dimanfaatkan sebagai bahan alternatif dalam pengendalian hama $C$. pavonana di lapangan. 


\section{DAFTAR PUSTAKA}

Bernard CB, Arnason JT, Philogene BJR, Lam J \& Waddell T. 1989. Effect of lignans and other secondary metabolites of the Asteraceae on the monooxygenase activity of European corn borer. Phytochemistry 28: 1373-1377.

Chou TC \& Talalay P. 1984. Quantitative analysis of dose-effect relationships: the combined effects of multiple drugs or enzyme inhibitors. Adv. Enzyme Regl. 22: 27-55.

Dadang \& Prijono D. 2008. Insektisida Nabati: Prinsip, Pemanfaatan, dan Pengembangan. Departemen Proteksi Tanaman, Institut Pertanian Bogor, Bogor.

Delfel NE, Tallent WH, Carlson DG \& Wolff IA. 1970. Distribution of rotenone and deguelin in Tephrosia vogelii and separation of rotenoid-rich fractions. J. Agric. Food Chem. 18(3): 385-390.

Elfahmi, Ruslan K, Batterman S, Bos R, Kayser O, Woerdenbag HJ \& Quax WJ. 2007. Lignan profile of Piper cubeba, an Indonesian medicinal plant. Biochem. System. Ecol. 35: 397-402.

Gaskins MH, White GA \& Martin FW. 1972. Tephrosia vogelii: a source of rotenoids for insecticidal and piscicidal use. http:// gears.tucson.ars.ag.gov/book/chap 9/ tephrosia.html [12 Desember 2009].

Georghiou GP. 1983. Management of resistance in arthropods. Pages 769-792 in: Georghiou GP \& Saito T, eds. Pest Resistance to Pesticides. Plenum Press, New York.

Gisi U. 1996. Synergistic interaction of fungicides in mixtures. Phytopathology 86: 1273-1279.

Hollingworth RM. 2001. Inhibitor and uncouplers of mitochondrial oxidative phosphorylation. Pp. 11691227 In: Krieger R, Doull J, Ecobichon D, Gammon D, Hodgson E, Reiter L \& Ross J, eds. Handbook of Pesticide Toxicology. Vol 2. Academic Press, San Diego.
Kamal, R. \& M. Mangla. 1993. In vivo and in vitro investigations on rotenoids from Indigofera tinctoria and their bioefficacy against the larvae of Anopheles stephensi and adults of Callosobruchus chinensis. J. Biosci. 18: 93101.

Kardinan A. 2002. Pestisida Nabati: Ramuan dan Aplikasi. Penebar Swadaya, Jakarta.

Klocke JA. 1987. Natural plant compounds useful in insect control. Pages 396-415 in: Waller GR, eds. Allelochemicals: Role in Agriculture and Forestry. ACS, Washington DC.

Kosman E \& Cohen Y. 1996. Procedures for calculating and differentiating synergism and antagonism in action of fungicide mixtures. Phytopathology 86: $1255-1264$.

Lambert N, Trouslot MF, Campa CN \& Chrestin H. 1993. Production of rotenoids by heterotrophic and photomixotrophic cell cultures of Tephrosia vogelii. Phytochemistry 34: 1515-1520.

LeOra Software. 1987. POLO-PC User's Guide. LeOra Software, Petaluma, California.

Metcalf RL. 1967. Mode of action of insecticide synergists. Annu. Rev. Entomol. 12: 229-256.

Morallo-Rejesus B. 1986. Botanical insecticides against the diamondback month. University of the Phillippines at Los Banos, College, Laguna, Phillippines.ht t p: / / w w w a v d . orgpdf86dbm86DBM23pdf [16 Maret 2007].

Oka IN. 1995. Pengendalian Hama Terpadu dan Implementasinya di Indonesia. Gadjah Mada University Press, Yogyakarta.

Perry AS, Yamamoto I, Ishaaya I \& Perry RY. 1998. Insecticides in Agriculture and Environment: Retrospects and Prospects. Springer, Berlin. 
Prijono D. 2002. Pengujuan Keefektifan Campuran Insektisida: Pedoman bagi Pelaksana Pengujian Efikasi untuk Pendaftaran Pestisida. Jurusan Hama dan Penyakit Tumbuhan, Fakultas Pertanian, Institut Pertanian Bogor, Bogor.

Prijono D \& Hassan E. 1992. Life cycle and demography of Crocidolomia binotalis Zeller (Lepidoptera: Pyralidae) on brocolli in laboratory. Indon. J. Trop. Agric. 4: 18:24.

Robertson JL, Russell RM, Preisler HK \& Savin NR. 2007. Bioassays with Arthropods. 2nd ed. CRC Press, Boca Raton.

Sastrosiswojo S. 1996. Sistem pengendalian hama terpadu dalam menunjang agribisnis sayuran. Hlm. 69-81 dalam: Prosiding Ilmiah Nasional Komoditas Sayuran. Lembang, 24 Oktober 1995. Balai Penelitian Tanaman Sayuran, Lembang-Bandung.
Sastrosiswojo S \& Setiawati W. 1993. Hama-hama kubis dan pengendaliannya. dalam: Permadi AH \& Sastrosiswojo S, eds. Kubis. Balithor, Lembang- Bandung.

Stone ND, Makela ME \& Plapp FW. 1988. Nonlinear optimization analysis of insecticide mixtures for the control of the tobacco budworm (Lepidoptera: Noctuidae). J. Econ. Entomol. 81: 989-994.

Usia T, Wabate T, Kadota S \& Tezuka Y. 2005. Potent CYP3A4 inhibitory constituents of Piper cubeba. J. Na.t Prod. 68: 64-68.

Wulan RDR. 2008. Aktivitas insektisida ekstrak daun Tephrosia vogelii Hook. f. (Leguminosae) terhadap larva Crocidolomia pavonana (F.) (Lepidoptera: Pyralidae) [skripsi]. Departemen Proteksi Tanaman, Fakultas Pertanian, Institut Pertanian Bogor, Bogor. 